\title{
The Kyoto Protocol: Two-Level Bargaining and European Integration
}

\begin{abstract}
:
The politics of ratifying the Kyoto Protocol may suggest a two-level game; yet, our quantitative analysis shows that ratification constraints did not affect bargaining over the Protocol, nor did bargaining outcomes affect ratification. The politics of the Kyoto Protocol are best understood as an example of the "Europeanization" of international politics: European countries subordinate their domestic politics to international cooperation, and the European Union emerges as a key agenda setter. We find that European countries ratified the Protocol in lock step and offered selective incentives - such as EU accession - to most of the participants. Case studies of Russia and Poland confirm our interpretation of the empirical findings.
\end{abstract}

\author{
Elena V. McLean \\ Texas A\&M University \\ Randall W. Stone \\ University of Rochester
}


Ratification by a sufficient number of parties brought the Kyoto Protocol into force in 2004, but the final agreement fell far short of the ambitions of the original U.N. Framework Convention on Global Climate Change. By this point, the scientific evidence of the severity of global climate change was much more impressive than it had been in 1992, and it became widely recognized that the Kyoto Protocol did not go nearly far enough to contain the risks. Why was international cooperation so ineffective and so difficult to achieve in this case? The United States failed to ratify the agreement, and Russia used the threat of non-ratification as a potent source of bargaining leverage. Successive rounds of bargaining whittled away at the cooperative agreement and the carbon emissions target steadily climbed. Domestic politics appears to be a leading contender to explain the outcome.

We propose two competing models of the politics of the Kyoto Protocol, and test them by analyzing the timing of ratification and the pattern of quantitative emissions quotas accepted by particular states. The first explanation is inspired by a two-level game framework, and argues that efforts to achieve an ambitious agreement were blocked by domestic politics. The testable implication is that the outcomes of bargaining should correspond to the obstacles to ratification: countries with severe domestic ratification constraints should receive more generous terms, but should be less likely to ratify (Putnam 1988; Tarar 2001). The alternative view rejects the premise that ratification posed an important constraint in most countries, and explains the pattern of outcomes in terms of strategic delegation to the European Union. This phenomenon has been called the "Europeanization" of international politics (Meunier and Wade 2007). In this view, European countries strategically subordinate their domestic politics to international 
cooperation in order to position the European Union as a key agenda setter in international institutions. A testable implication of this view is that ratification depends upon countries' relationships with the European Union rather than upon domestic politics, so that domestic ratification constraints do not translate into effective bargaining leverage. In particular, we expect that membership in the European Union or pending applications to join the EU explain most of the variation in bargaining outcomes and ratification. We test each model's implications using quantitative analysis of the time to ratification and the quota allocations made at Kyoto (1997) and subsequently revised at Marrakesh (2001).

The Kyoto Protocol represents an unusual opportunity to test models of two-level bargaining because it has a large number of participants and the quantitative carbon emissions quotas provide an index of bargaining outcomes. Furthermore, effective quotas were revised at Marrakesh in 2001 by allowing credits for carbon sinks, which made it possible for the on-going processes of ratification and renegotiation to influence each other. Surprisingly, however, we find no evidence of endogeneity: bargaining outcomes do not affect ratification, and expected ratification does not affect bargaining outcomes. Thus, although the two-level game argument implies simultaneous effects that would indicate the need for a simultaneous equations approach, our findings reject this hypothesis. Consequently, we test our hypotheses using a series of recursive models: duration models to analyze the ratification process and least squares to analyze the carbon emissions quotas. ${ }^{1}$

\footnotetext{
${ }^{1}$ The recursive models are more efficient than the full, two-stage equations with instrumental variables. A Hausman test yields a test statistic of -1.25 , indicating that we cannot reject the null hypothesis that the two equations are independent. Consequently, the recursive model specification is appropriate for our analysis.
} 
Models of bargaining under incomplete information predict that information about political constraints that is publicly available ex ante-i.e., when the bargaining takes place — should be incorporated into bargaining outcomes, and consequently should not affect the probability that cooperation breaks down (Fearon 1994). Private information or information that is observed only ex post, however, or after an agreement has been signed, should not be reflected in bargaining but should affect ratification. Consequently, to test for effects of domestic politics on bargaining and ratification, we use political constraints observed at the time of bargaining to explain bargaining outcomes, and political constraints observed during the run-up to ratification to explain ratification. However, in order to test the proposition that expectations about ratification may affect bargaining, we generate predicted values for ratification based only on the information available at the time of bargaining, and test for effects of this predicted probability on the pattern of concessions. We then use the ex post data on domestic political constraints and realized bargaining outcomes to explain the pattern of ratification.

\section{Domestic Politics and International Bargaining Power}

Thomas Schelling made the observation, which has subsequently become part of the conventional wisdom about international relations, that domestic political opposition can be a source of international bargaining leverage (Schelling 1960). Bayne and Putnam (1984) referred to this domestic-international interaction as a "two-level game," arguing that Helmut Schmidt used domestic constraints deftly in 1978 at the Bonn G-7 summit to extract concessions from the United States on energy policy and from Britain on trade policy in return for launching a modest fiscal expansion that he personally favored. 
Putnam (1988) systematized this mechanism; subsequent formal work has explored the conditions under which domestic constraints can shift bargaining outcomes and even improve a leader's welfare (London 2002; Tarar 2001); and empirical work has shown that ratification constraints have important effects on international bargaining (Evans et al. 1993; Martin 2000).

With a few exceptions, work in the two-level game literature shares a theoretical blind spot: it generally treats only leaders as strategic, and models domestic political actors as myopic. Domestic agents are often modeled simply as constraints; and when they enter the game as strategic actors in their own right, they have preferences only over the domestic implications of international agreements. When domestic actors are hypothesized to have interests regarding international agreements, as in the audience cost literature, they are typically replaced with non-strategic parameters (Fearon 1994, Leventoglu and Tarar 2005). Kenneth Schultz (2001) extends the audience cost logic to allow the opposition party to be rational, but the voter remains an irrational black box. It remains unclear in these accounts why domestic audiences should punish their leaders for making concessions, even when doing so is in their own interest.

Why should we believe that only leaders are able to take a broad view of the national interest, and that legislators and voters are not able to vote strategically in order to achieve international policy objectives? A notable exception is Mansfield, Milner and Rosendorff (2000), which finds that when legislators have preferences over both protection at home and protection abroad, democratic countries may make deeper concessions to each other than to autocratic countries precisely because both sides face domestic constraints. Strategic legislators agree to deeper cuts in domestic protection 
than they would otherwise prefer, because they know that is the only way to induce legislators in the neighboring country to accept deep cuts in their own trade barriers. When this kind of strategic coordination is difficult to achieve, however, domestic political actors could exercise collective strategic restraint by delegating functions to an international organization (Hawkins et al. 2006). In a similar way, the Reciprocal Trade Agreements Act of 1934 was seen as a way for Congress to delegate authority to the U.S. president in order to overcome coordination problems and increase national bargaining power (Haggard 1986). In an increasingly interdependent world economy, delegating powers to an international agency may be the only way to achieve certain objectives (Keohane, Macedo and Moravcsik 2009).

Strategic delegation has been a driving force behind European integration, which dampens the effects of domestic politics, and increases European influence in international politics as a result. In many respects, the Bonn summit of 1978 was the high point of disorganization in Europe, when domestic politics appeared to pose insuperable obstacles to broad European cooperation and each country was left to bargain bilaterally. Discordant monetary policies ultimately drove Britain into a humiliating agreement with the IMF that proved politically disastrous for the Callaghan government. Many of the subsequent developments in European integration can be interpreted as attempts to coordinate domestic policies in order to prevent domestic politics from undermining Europe's potential bargaining leverage in world politics. For example, the European Monetary System was developed as an effort to dampen the wild swings in European bilateral exchange parities following the demise of the Bretton Woods system of fixed exchange rates. Coordinating exchange rate and monetary policies was a way to 
reduce vulnerability to changes in U.S. monetary policy (Henning 1998). ${ }^{2}$ The subsequent move to Economic and Monetary Union had numerous motivations, but important among them were increasing Europe's weight in the world and reducing its vulnerability to the vacillations of U.S. monetary policy. EMU has increased the importance of the European Union in G-7 deliberations and in the IMF, where EU Executive Directors have announced their intention to vote as a bloc.

In order for strategic delegation to succeed, however, it must be credible. Schneider and Cederman (1994) aptly described the politics of European integration as an asymmetric-information bargaining game, where the stakes are integration and exclusion. Dramatic advances in European integration occur when threats to exclude laggards are credible; stalemate occurs when the pressure for integration is too weak to overcome domestic political constraints. For example, the integration of European financial markets in the Single European Act is commonly depicted as the consequence of a French strategic choice under Mitterrand to give up domestic policy autonomy in return for greater opportunities to manage international policy externalities at the European level (Helleiner 1994; Abdelal 2007). However, it was equally a consequence of the credible threat by France and Germany to exclude the United Kingdom if it attempted to block agreement (Moravcsik 1998). As a new European consensus emerged in favor of financial liberalization, as Abdelal demonstrates, European influence in other financial institutions expanded and the same policy preference became hegemonic. In both the OECD and the IMF Executive Board, the synchronized shift in positions by the European governments set the new agenda.

\footnotetext{
${ }^{2}$ The U.S. policy of letting the dollar fall — the use of the "dollar weapon" — exported inflation and shifted the cross-exchange rates between European currencies because European countries chose different responses to the common external shock.
} 
The transformation of European trade policy presents the most dramatic examples of European governments surrendering domestic policy autonomy in order to gain bargaining power (Meunier 2005). Pascal Lamy labeled this shift "managing globalization," explicitly linking the priority for European integration to increased ability to manage the policy externalities originating outside of Europe. Pooling the bargaining power of European countries made it necessary to construct a single market that could make coordinated concessions, and this was one of the key arguments in favor of the Single European Act. With a common bargaining position, European countries were able to face the United States on equal terms in trade, and this bilateral interaction set the agenda in the Uruguay GATT round (Grieco 1990) and subsequently in the WTO (Barton et al. 2006). However, a common bargaining position did not guarantee strategic delegation; instead, French opposition to any agreement that would hurt its powerful farm lobby threatened to derail the Uruguay Round. The domestic political constraints were intense, and France had traditionally acted as a veto player on reform of the Common Agriculture Policy. When the Uruguay Round deadlocked over agriculture subsidies, however, the other European countries overrode French objections to a package deal (Davis 2003). When the international stakes become high enough, domestic political constraints can be overridden.

Ordinary policymaking in the European Union does not resemble these instances of high-stakes bargaining, because European countries generally defer to each others' domestic constraints. Indeed, it is rare for decisions to be made by qualified majority voting even when treaty provisions call for it, because a norm has arisen of mutual deference, and European diplomats seek consensus decisions (Thompson et al. 2006 ; 
Pollack 2003). Variation in the credibility of strategic delegation occurs across issues, depending upon the stakes, and exclusion is most credible during major constitutional changes in European institutions, such as the negotiation of the Single European Act and Economic and Monetary Union. However, the existence of countries that were candidates for admission to the EU during the Kyoto process provides a way of measuring the effect of variations in the credibility of exclusion.

New candidate members are more credibly subject to exclusion for noncompliance than existing members, and as a result delegation to the European Union reaches a high point during the accession process. Accession negotiations are very onesided (Schneider 2009). Countries that join the EU derive substantial benefits, but in return they accept the obligation to adopt an extensive body of European legislation, the acquis communitaire, to honor all treaties to which the EU is a party, and to implement a series of negotiated accession criteria. As a result, the accession process leads to an extraordinary temporary suppression of domestic politics. EU integration must be accepted or rejected by the legislative branch as a package deal, with very little opportunity for domestic political interests to influence the results. New members can subsequently influence the development of EU legislation, but supermajority voting and consensus decision making confer staying power on the status quo. Indeed, the desire to manipulate the agenda by shaping the status quo is a prominent explanation for the pattern of sequential admission of new members (Downs, Rocke and Barsoom 1998).

The model of two-level bargaining and the hypothesis of delegation to the EU generate distinct theoretical expectations. Two-level bargaining assumes that domestic ratification constraints are binding, so that bargaining outcomes reflect the difficulty of 
achieving domestic ratification, and the prospects of ratification depend upon achieving an attractive settlement at the international level. In contrast, the delegation hypothesis assumes that domestic ratification constraints are not binding on members of the European Union, so they should be most likely to adopt ambitious environmental goals and to subsequently ratify agreements. These effects should be most marked for EU accession countries, because strategic delegation is most effective when the threat of exclusion is credible. The efficacy of accession countries' domestic institutional constraints is temporarily suppressed as they seek to promote their candidacies.

\section{The Kyoto Bargaining Process}

Bargaining is a substantial obstacle to international cooperation, because low discount rates, which are a necessary condition for successful cooperation, are also the condition that makes bargaining most costly (Fearon 1998). The fate of the Framework Convention on Climate Change is a sobering case in point. Global climate change is a long-term problem, so the countries that are most interested in ameliorating its risks are those with the lowest discount rates; because they are patient, they have the strongest incentives to hold out for a better deal. The beginning was auspicious: soon after a scientific consensus on the problem emerged, an agreement was signed at the United Nations Conference on Environment and Development in Rio de Janeiro in 1992, which was eventually signed by one-hundred ninety-four countries (Bodansky 2001). Members of the OECD and twelve post-Communist countries agreed to stabilize their emissions at 1990 levels by 2000, and to work on an agreement to reduce emissions in the second 
decade. ${ }^{3}$ However, the process of turning non-binding principles into concrete commitments gradually eroded the emissions target.

The 1997 Kyoto Protocol contained binding treaty obligations but fell short of expectations in several respects. First, the developing countries refused to adopt binding emissions targets, and three OECD members (South Korea, Mexico, and Turkey) likewise avoided emissions quotas. Second, the targets adopted were not ambitious. The negotiated quotas called for a 3.6\% aggregate reduction of $\mathrm{CO}_{2}$ from 1990 levels, which fell far short of the European goal of negotiating 15\% emissions reductions (Den Elzen and de Moor, 2001). National targets ranged from 8\% reductions from 1990 levels for the European Union and some post-communist countries to $7 \%$ for the United States, $6 \%$ for Japan, and $0 \%$ for Russia and Ukraine, and even permitted emission increases of $1 \%$ for Norway, $8 \%$ for Australia and 10\% for Iceland.

In spite of the weakening of the accord, the most important producer of greenhouse gasses failed to ratify. In the lead up to Kyoto the U.S. Senate had passed the Byrd-Hagel Resolution, opposing any agreement that failed to impose restrictions on developing countries, or that imposed substantial costs on the U.S. economy-two conditions that were unavoidable in any feasible treaty. ${ }^{4}$ The European negotiators viewed this as a bargaining tactic, and assumed that the Clinton Administration could

\footnotetext{
${ }^{3}$ As it happened, the advanced industrial countries increased their emissions, while post-Communist countries reduced their emissions because of the collapse of industry during the 1990s.

${ }^{4}$ The Byrd-Hagel Resolution stated, in part, "Resolved, That it is the sense of the Senate that the United States should not be a signatory to any protocol to, or other agreement regarding, the United Nations Framework Convention on Climate Change of 1992, at negotiations in Kyoto in December 1997, or thereafter, which would (A) mandate new commitments to limit or reduce greenhouse gas emissions for the Annex I Parties, unless the protocol or other agreement also mandates new specific scheduled commitments to limit or reduce greenhouse gas emissions for Developing Country Parties within the same compliance period, or (B) would result in serious harm to the economy of the United States..." (Byrd-Hagel 1997).
} 
nevertheless bully, bargain or buy a majority in the Senate to ratify the Protocol.

President Clinton judged otherwise, however, and chose not to submit the Protocol to the Senate for ratification. In March 2001, the Bush administration announced its rejection of the Kyoto Protocol because the treaty was deemed "fatally flawed in fundamental ways:" it would harm the American economy and would do nothing to restrain emissions by developing countries.

The rigor of the commitments adopted at Kyoto deteriorated further at subsequent conferences. Negotiations continued on a range of issues, including emissions trading and carbon sinks. Policies that remove $\mathrm{CO}_{2}$ from the atmosphere such as reforestation, land management and some forms of agriculture could make a country eligible for credits against its emissions reduction target known as removal units (RMUs). These credits effectively relaxed the commitments that had already been reached: the average quota at Kyoto represented a reduction of emissions to $96.6 \%$ of 1990 levels, but after the agreement on implementation mechanisms at Marrakesh in 2001, the effective quota represented a target of $101 \%$ of 1990 emissions (den Elzen and de Moor 2001). While the European Union countries rapidly ratified the Protocol after Marrakesh, other countries insisted on receiving larger increases in their effective quotas.

\section{Quantitative Analysis}

We test a two-level bargaining model and a European integration model, and we present results of regressions customized to test each hypothesis. As noted above, we find no evidence of endogeneity, so we do not use a simultaneous equations approach; instead, we present the results of separate analyses of the bargaining and ratification 
phases of the Kyoto process. We first estimate a forecasting model of the probability of ratification, which uses only ex ante information. By ex ante information we mean information that was publicly known when the Kyoto agreement was signed in 1997 about country-level factors that might subsequently affect ratification. ${ }^{6}$ This generates our estimates of the expectations about ratification at the time of agreement. Next we estimate models of ratification using ex post information, which is all of the available information about political constraints and bargaining outcomes as they evolved over time. These are the models relevant for testing our hypotheses about ratification.

Finally, we estimate models of the bargaining over quotas, which incorporate our ex ante estimates of the probability of ratification.

\section{Data and Variables}

To test the hypotheses derived from the two theoretical frameworks, we created two corresponding sets of variables. For the two-level bargaining model, the measures of primary interest are effective emissions caps agreed under the Kyoto Protocol and the Marrakesh Accords, in millions of tons of $\mathrm{CO}_{2}$. The two variables, Effective quotas after Kyoto and Effective quotas after Marrakesh, were constructed to measure the economic cost of ratification: The prediction from a forecasting model of counterfactual $\mathrm{CO}_{2}$ production is subtracted from the negotiated quota to determine how much excess $\mathrm{CO}_{2}$ production each country would be allowed (or, if negative, how much each would have to curtail its production) if it ratified the Protocol after Kyoto or after the modifications adopted at Marrakesh. ${ }^{7}$ For the European integration model, we created three dummy

\footnotetext{
${ }^{6}$ Estimation techniques chosen for this stage are Weibull duration models and, as a robustness check, logit with splines.

${ }^{7}$ Appendix B discusses robustness checks with alternative measures of effective emissions quotas.
} 
variables. EU15 captures the effect of EU membership, and takes the value of 1 for each of the first fifteen EU members, and 0 otherwise. EU applicant (first group) and EU applicant (second group) gauge the influence of the EU accession process. EU applicant (first group) equals 1 if a country was in the advanced group of accession states that were approved by the European Commission for accession negotiations in 1997 (Poland, Hungary, Estonia, Slovenia, the Czech Republic, and Cyprus), and 0 otherwise. EU applicant (second group) takes the value of 1 for countries in the accession group approved in 1999 (Slovakia, Latvia, Lithuania, Bulgaria, Rumania, and Malta), and 0 otherwise,

We also use several control variables to account for the factors analyzed in the existing literature. Negotiations are likely to reflect economic disparities between participating countries: on the one hand, population numbers and economic size are linked to total-country emissions and should, in turn, affect emissions quotas (Wiegandt 2001). On the other hand, these factors may also affect the countries' willingness to ratify the climate change agreement, as economic priorities may overshadow environmental concerns (Sprinz and Weiß 2001; Ward, Grundig and Zorick 2001).. Accordingly, we include the Population and GDP variables in the ratification and quota analyses.

Previous research also suggests that domestic politics may act as important determinants of international policies. In particular, Sprinz and Weiß (2001) argue that domestic forces shaped international climate policy-making. We use several variables from the Database of Political Institutions (2006) to operationalize domestic political constraints that may affect treaty ratification. The Parliamentary dummy takes the value of 1 for countries, in which the legislative branch elects the chief executive, and 0 
otherwise. Opposition majority indicates whether or not an opposition party holds an absolute majority in the House, which has lawmaking powers. Fractionalization gauges the degree of legislative fractionalization and is calculated as the probability that any two legislative representatives picked at random will be of different political parties. Legislative election timing counts the number of months remaining until the next legislative election. Finally, Left-right is an indicator of the government's economic position: the values range from -3 for a far left government, to 3 for a far right government.

Two additional control variables are used in ratification timing tests. First, we created a dummy variable for OPEC countries to account for this group's economic interest in increasing fossil fuel consumption and, consequently, hindering the adoption of the Kyoto Protocol. OPEC countries first sought to veto any agreement during climate negotiations prior to 1996 when countries sought to reach consensus. When the adoption of the Geneva Ministerial Declaration signaled countries' willingness to act without consensus, OPEC members pushed for a provision that would acknowledge the negative impact of climate change mitigation measures on their economies (Bodansky 2001). Since only Annex B countries adopted binding targets for $\mathrm{CO}_{2}$ emissions reduction, we included a second dummy variable, which takes the value of 1 for Annex B countries, and 0 otherwise.

Control variables included in the effective quotas analyses capture the factors that were explicitly discussed during climate change negotiations and then reflected in the resulting international agreements. One of the most salient measures is the amount of $\mathrm{CO}_{2}$ produced by a given country. While carbon dioxide is not the only greenhouse gas 
regulated by the Kyoto Protocol, it is widely recognized as the most significant contributor to global warming. Therefore, we include a variable that gauges the total amount of $\mathrm{CO}_{2}$ that a country emits annually, measured in kilotons. In addition to the amount of produced pollution, negotiations over emissions quotas considered possible offsets, such as emissions reductions achieved through certain types of land use and forestry activities, incorporated both in the Kyoto Protocol and the Marrakesh Accords. While we do not have direct measures of such qualifying activities, we use two proxies the total amount of land and forest in each country ${ }^{8}-$ as the most appropriate available indicators. Another form of offset that some countries received is through the use of an alternative base year for the purposes of calculating total emissions reductions. More specifically, post-communist countries of Eastern Europe and the Former Soviet Union pushed successfully for the principle that their emissions allowances should be calculated on the basis of pre-1990 base years, since their emissions had already declined significantly by 1990 due to the disruptive effects of economic transition (Ward, Grundig and Zolick 2001). The Post-communist dummy is included to control for the effect of the adjusted formula used to calculate emissions quotas for this region.

\section{Explaining the Ratification Stage}

Table 1 displays estimation results from Weibull duration models of the ratification stage using ex ante and ex post information. The first column uses only data known at the time of signing the Protocol to predict ratification ${ }^{9}$; subsequent columns use

\footnotetext{
${ }^{8}$ The source of data for these variables, as well as GDP and Population, is World Development Indicators.

${ }^{9}$ We replicated the analysis for the ex ante information case using logit with splines (Beck, Katz and Tucker 1995). We do not report these results in the paper because they are essentially the same as our Weibull estimates.
} 
contemporaneous data and control for the effective emissions caps agreed under the Kyoto Protocol and the Marrakesh Accords, ,

The results are not encouraging for the theory of two-level bargaining. Our main result is that the effective limit on $\mathrm{CO}_{2}$ emissions allowed under the agreements has no significant effect on the timing of ratification. Neither Effective quotas after Kyoto nor Effective quotas after Marrakesh achieves statistical significance. Therefore, we cannot reject the null hypothesis that the negotiated outcomes had no effect on the length of national ratification processes. This severs an essential logical link in the two-level game hypothesis: In order for bargaining to depend upon ratification constraints, ratification must depend on bargaining outcomes. We find no evidence, however, that bargaining outcomes affect ratification. [Table 1 here]

Table 1 also reports our findings from a test of the alternative hypothesis, which was that the Kyoto process was overshadowed by European integration. The ratification models include three dummy variables to capture effects of the EU's influence on three groups of countries: EU15 countries, the advanced group of accession states that were approved for accession negotiations in 1997, and the second accession group approved in 1999. According to the European delegation perspective, member nations should ratify the climate change treaty sooner in order to position the European Union as a key agenda setter in the international climate change regime. For accession countries, our expectation was that they were under pressure to ratify the Kyoto Protocol—indeed, to adopt all treaties to which the EU was a party, which was a condition for completing the EU accession process. These were the countries whom the promise of EU membership made willing to make sacrifices in order to achieve it. The results support this 
hypothesis. EU members and both groups of candidates for EU accession were significantly more likely to ratify Kyoto rapidly than other countries.

Ratification in the full panel of countries is noisy, because ratification has very different implications for Annex B countries, which bear the costs of reducing their carbon emissions, and countries that have taken on no obligations. Consequently, we replicate the tests on the smaller sample of Annex B countries. These tests, presented in the last two columns of Table 1, yield robust support to the EU hypothesis and provide no evidence in favor of the two-level game perspective. Both EU members and EU candidates ratify the Kyoto Protocol sooner than non-EU countries, whether controlling for effective quotas as negotiated at Kyoto or as subsequently modified at Marrakesh. The coefficients on the quotas variables never reach statistical significance.

When we restrict the sample to Annex B countries, we also find that domestic political factors affect the ratification process. Parliamentary political systems join the climate change regime sooner than countries with presidential systems; however, ratification is delayed when a single opposition party controls a majority in the lower house of parliament. Ratification is particularly dilatory when right-wing parties control the government. On the other hand, neither legislative fractionalization nor the timing of legislative elections appears to have a statistically significant effect on the ratification process.

Previous research suggested that pressing economic issues crowd out environmental concerns; therefore, large economies, sizeable populations, and dependence on oil production can be expected to hinder ratification (Sprinz and Weiß 2001; Ward, Grundig and Zorick 2001). In our tests, however, both on the full and 
Annex B samples, GDP and population size do not have statistically significant effects on ratification timing. Only when we use the full sample, which enables us to include the OPEC dummy, we find evidence of oil-producing countries' concern regarding the Kyoto Protocol's adverse impact on their economies. The states that take longest to become Kyoto parties are, in fact, the members of OPEC, which have an economic interest in high levels of fossil fuel consumption. Of the eleven oil cartel members, only two have ratified the Kyoto Protocol (Nigeria acceded in December 2004, and Qatar did so in January 2005). From a bargaining perspective, we would also expect that countries that adopted binding obligations under the Kyoto Protocol would be reluctant to ratify it. Yet, our full sample results suggest that Annex B countries, which adopted potentially costly obligations, were not more wary of ratifying than free riders. We attribute this surprising finding to the fact that out of thirty-six Annex B countries, twenty-seven were either EU members or accession candidates.

\section{Bargaining Outcomes: Explaining the Levels of Effective Quotas}

What accounts for the pattern of bargaining outcomes negotiated at Kyoto, and revised and substantially relaxed at Marrakesh? According to the theory of two level games, bargaining outcomes should depend upon domestic political constraints, and in particular should reflect the probability of ratification. The results presented in Table 2 test this link. The dependent variable is the effective $\mathrm{CO}_{2}$ quota, which is measured as the difference between the country's emissions quota and its projected $\mathrm{CO}_{2}$ output in the year 2010. ${ }^{11}$ The variable of primary theoretical interest from the two-level game perspective is the ex ante predicted median ratification time from the duration model reported in the

\footnotetext{
${ }^{11}$ The construction of the variable is described in detail in Appendix A.
} 
first column of Table 1. This variable is statistically insignificant, so the null hypothesis that ratification timing has no effect on the size of quotas cannot be rejected. This drives a final nail into the coffin of the two-level game hypothesis. We found above that bargaining outcomes do not appreciably affect ratification; now we see that expectations about ratification are not related to bargaining outcomes. There is no evidence of the strategic interdependence postulated between bargaining and ratification. While this is anomalous for the two-level game hypothesis, it is consistent with the European delegation approach - domestic actors in EU member and candidate countries cannot credibly threaten to obstruct ratification when the incentives applied by international institutions are intense. [Table 2 about here]

To conduct more direct tests of the hypothesis that the EU exerted influence over the Kyoto process, particularly on prospective member states, we restrict the sample to the set of countries that accepted obligations under the Kyoto Protocol. We present results using the effective quotas after Kyoto (1997) as the dependent variable in the second column, and the quotas as revised at Marrakesh (2001) in the last one. Table 3 illustrates the substantive effects of the variables with selected marginal effects and predicted values. [Table 3 about here]

Our analysis of the determinants of the level of effective $\mathrm{CO}_{2}$ quotas yields robust evidence in favor of the EU-centered perspective. The striking result is that EU applicants agree to terms that are more constraining than those for other Annex B countries. ${ }^{12}$ The substantive effect of applying for EU membership is costly: When all

\footnotetext{
${ }^{12}$ Note that the reference group in Table 2 includes the United States, Norway, Switzerland, Canada, Japan, Iceland, Australia, and New Zealand. The differences between this group and other Annex B countries (EU members, candidates, and post-communist states) are significant. On average, the countries in the reference group will have to reduce emissions by 194 megatons, while other Annex B countries will have 39
} 
variables are at their mean values, changing the advanced EU applicant group dummy from 0 to 1 turns surplus $\mathrm{CO}_{2}$ emissions quotas that could have been traded for cash into emission cuts of 295 megatons under the Kyoto Protocol or 301 megatons after the Marrakesh Accords. EU applicants approved for accession in 1999 adopt reductions of a similar magnitude. Older EU members, on the other hand, do not accept equally disadvantageous conditions under the climate change agreement.

Several control variables have significant effects on $\mathrm{CO}_{2}$ reductions. As expected, larger countries were offered more lenient terms under the Kyoto Protocol, i.e. a more favorable difference between their quotas and projected emissions, presumably because the agreement had been structured to make their participation necessary in order to bring it into force. Post-communist states also found themselves in a privileged situation, receiving quotas that allow them to produce $\mathrm{CO}_{2}$ above their projected levels. Surprisingly, more affluent countries do not appear to have accepted a greater level of responsibility in mitigating negative environmental side effects of their economic development. On the other hand, the level of $\mathrm{CO}_{2}$ emissions does have the anticipated effect on countries' expected reductions — heavy producers of carbon dioxide emissions, such as the United States, are expected to bear a larger share of efforts to ameliorate the problem. Of the two types of emissions offsets mentioned in the Kyoto Protocol and the Marrakesh Accords, only land area provides countries with more lenient terms, while forests are not related to effective quotas. This non-finding is surprising because

megatons of emissions to sell . Because of the inclusion of the United States, the reference group has a much higher average GDP, 1.8 trillion USD as compared to the mean of 181 billion USD for other Annex B states, and produces more pollution (in 1998, an average country in this group emitted 943 megatons of $\mathrm{CO}_{2}$ alone, while other Annex B states produced only 199 megatons of this greenhouse gas, on average). Finally, the reference group comprises states that are larger than other Annex B countries both in terms of population (with an average of 58 million people - compared to 24 million of other Annex B states) and land area (with an average of 3,392,669 square $\mathrm{km}$ - compared to 775,269 square km in other Annex B states 
protection of forests was presented as a primary justification for instituting emissions credits for carbon sinks.

\section{Cases}

We investigate two cases in order to probe the plausibility of the interpretations we have made of our findings in the previous section. Both the Russian Federation and Poland are Annex B countries; Russia is neither an EU member nor an EU candidate, and Poland was in the first group of countries admitted to candidacy in 1997. The first case, Russia, was chosen because it appears to be anomalous for our interpretation of the aggregate data. If any country bargained successfully for generous quotas and extracted concessions by threatening to withhold ratification, Russia was that country. Indeed, Russia's ratification drama made front page news in international newspapers, so it was the leading example that suggested the two-level bargaining hypothesis. Can we learn something about the Russian bargaining and ratification process that can explain why we find so little evidence of endogenous bargaining and ratification effects in the quantitative analysis? The second case, Poland, represents an opportunity to trace out the process by which EU influence makes itself felt in a case that ought to lie close to the regression line. Poland was always in the front ranks of candidates for EU expansion; in fact, many observers assumed that an EU expansion that excluded Poland was as unthinkable as an EU expansion that included Russia. Our objective here is to determine whether our interpretation of our regression coefficients is plausible. Is it true that the process of EU expansion in fact eclipsed the Kyoto Protocol? Were the fractious domestic politics in 
Poland rendered moot by the prospect of joining the European Union? Was Poland able to use domestic constraints to bargain for concessions, or was it simply compelled to adopt and ratify the Kyoto Protocol as the price of joining Europe?

\section{Russia}

Russia was quick to seize the opportunity to sell its emissions allowances soon after ratifying the Kyoto Protocol. In June 2005 Russia's electricity monopoly, Unified Energy Systems, and the Danish Environmental Protection Agency signed an agreement for the sale of emission credits. Two UES subsidiaries, Khabarovskenergo and Orenburgenergo, were the beneficiaries of the agreement: the Danish government made a commitment to invest 20 million euros in the modernization of two electric power plants, one in the Khabarovsk region, and the other in the Orenburg region. The improved facilities were expected to reduce their $\mathrm{CO}_{2}$ emissions by more than a million metric tons, which would help Denmark meet its emissions target. All cheap talk aside, Russian authorities have not shown any sign of concern that the obligations adopted under the Kyoto Protocol pose any risk of braking Russia's rapid economic expansion.

Russia reaped the grand prize for brinkmanship during Kyoto negotiations. The country had already secured high quotas at Kyoto, allowing it to restore its production of greenhouse gases to $100 \%$ of 1990 levels, although actual levels had fallen $28 \%$ during the transition of the 1990s. The predicted effects from the regression reported in Table 2 illustrate the strength of Russia's bargaining position. While the average Annex B country will have to reduce its emissions by 22.9 megatons of $\mathrm{CO}_{2}$ under the Kyoto Protocol or by 9.7 megatons of $\mathrm{CO}_{2}$ after the Marrakesh revisions, relative to the 1990 
emissions level, Russia is predicted to have excess emissions allowances of 520 and 615 megatons of $\mathrm{CO}_{2}$, respectively, under the Kyoto and Marrakesh rules.

After the United States dropped out of the Kyoto Protocol and other large polluters (China and India) refused to join the economically costly environmental agreement, Russia's participation became crucial for the climate change regime. The Protocol could not enter into force until

...not less than 55 Parties to the Convention, incorporating Parties included in Annex I which accounted in total for at least 55 per cent of the total carbon dioxide emissions for 1990 of the Parties included in Annex I, have deposited their instruments of ratification, acceptance, approval or accession. ${ }^{15}$

The '55 Parties' requirement was satisfied when Iceland ratified the treaty on May 23, 2002. The second condition proved to be more challenging. Once the United States withdrew its support for the Protocol, ratification by Russia—which accounts for $17.4 \%$ of the world's greenhouse gas emissions - became arithmetically necessary to bring the agreement into force. President Vladimir Putin played his cards skillfully to extract the maximum possible advantage. At Marrakesh, Russia successfully pushed for a nearly twofold increase of its sinks credit for forest management, thereby increasing its effective target to $105 \%$ of 1990 levels, so that Russia would have substantial excess quotas to sell throughout the duration of the agreement under any likely prognosis of Russian economic growth. Nevertheless, Russia withheld ratification and threatened to scuttle the agreement.

The apparent source of Russia's influence at Marrakesh was the uncertainty created by two streams of opposition emerging at the national level. On the one hand, Russian scientists questioned the scientific foundations of the Kyoto Protocol. The

\footnotetext{
${ }^{15}$ Paragraph 1 Article 25 of the Kyoto Protocol.
} 
Russian scientific community disputed the assertion that $\mathrm{CO}_{2}$ was the main driving force behind climate change, that emissions from human-made sources made a difference in global processes, and even that the global climate was becoming warmer. The President of the Russian Academy of Sciences, Yurii Osipov, wrote a letter to President Putin that criticized the Protocol for its "lack of scientific foundation," and argued that the treaty would be of "little help in reducing the concentration of greenhouse gasses in the atmosphere as called for by the U.N. Framework Convention on climate change."16 On the other hand, there was general agreement that retooling a very energy-intensive economy would entail huge costs if the Russian economy continued its rapid pace of growth, and politicians and government officials expressed skepticism about the benefits of the Kyoto Protocol. Putin's economic policy advisor, Aleksei Illarionov, opposed the treaty because it would hamper the growth of Russia's economy and because its ecological impact would be marginal, especially without the participation of other major polluters, prominently including the United States. To emphasize the negative effects that he argued Kyoto quotas would have on economic development, Illarionov stated that "the Kyoto Protocol is based on the most insolent intervention in economic growth, in particular, and the development of human civilization, in general, and it can be compared to fascism." 17

Hyperbole aside, Russia's emissions allowances under the climate protection treaty were high enough for the country to be able to meet its reductions commitments and to benefit from emissions trading at the same time. Furthermore, it was not an

\footnotetext{
${ }^{16}$ „Academics Directed a Letter to President Putin against the Kyoto Protocol,“ Gazeta.ru (May 18, 2004). www.gazeta.ru/2004/05/18/last121083.shtml.

17 „Putin Advisor Compares Kyoto Protocol to Fascism,“ MosNews (September 27, 2004). www.mosnews.com/money/2004/09/27/illarionovkyoto.shtml.
} 
expectation of a long and difficult ratification process at the national level that gave Russia its leverage in the Kyoto process, as there could hardly be any concern about the ability of the Russian government to secure the State Duma's ratification of the Kyoto Protocol. The pro-presidential party, United Russia, held the majority of seats in the parliament, and the parliament under Putin was no longer the fractious and independent Duma of Boris Yeltsin's tenure. Government-sponsored legislation was passed with startling speed, and the opposition was suddenly eager to please. Independent criticism of the government became muffled, independent news outlets were curtailed and largely exiled from the capital, and candidates were intimidated to keep them out of sensitive races. As the sphere of democratic rights and freedoms shrank, the credibility of the claim that democratic institutions represented a constraint on central authority became strained.

Nevertheless, it was clear that Russia did not intend to join the Kyoto Protocol without securing some concessions outside the Kyoto regime in exchange. Putin confided his private view on Russia's ratification to Valerii Bogomolov, the first deputy chairman of the United Russia parliamentary faction: "Probably we will have to adopt it some time, but neither soon, nor quickly." 18 The concession that Putin had in mind was achieving the centerpiece of his internationalist economic policy, membership in the World Trade Organization. He had acquiesced in the basing of American troops in Uzbekistan in return for U.S. support; now he threatened to scuttle the climate change regime if not assured of EU support. Under WTO rules, the EU was capable of blocking Russia's accession indefinitely. The EU insisted upon a long-standing demand that

\footnotetext{
${ }^{18}$ Meeting with Valerii Bogomolov and a delegation of members of the Russian Duma, Stiftung Wissenschaft und Politik, Berlin, Germany. June 18, 2004.
} 
Russia allow its domestic natural gas prices to rise to world market levels before it could enter the WTO, arguing that below-market gas prices represented an unfair subsidy to Russian exporters and import-competing industries. In the end, the European Union blinked, offering a surprisingly frank quid pro quo that would smooth Russia's frozen application to the WTO in return for ratification of the Kyoto Protocol. The irony was not lost on observers that joining the Kyoto Protocol would do much less to reduce Russian emissions of greenhouse gasses than raising its domestic natural gas prices to world levels would have done. For our purposes, however, the striking fact is that Russia turns out not to be such an outlier after all. Russia was not a candidate for accession to the EU, but it was nevertheless the EU that purchased Russian adherence to the Kyoto Protocol, albeit with a different coin.

The domestic disagreements over the treaty did not affect the ratification process once President Putin voiced his support for the Kyoto Protocol and encouraged the government to prepare all the necessary ratification documents as soon as possible. On October 22, 2004, the State Duma passed the ratification bill, which received 334 votes in favor, and only 73 opposed. The Federation Council gave its approval in five days, and on November 5 President Putin signed the bill into law, concluding the accelerated ratification process.

\section{Poland}

Poland ratified the United Nations Framework Convention on Climate Change on July 28,1994 . After five years of economic transition accompanied by a significant drop in industrial activity, meeting the emissions target was unproblematic because greenhouse gas emissions had decreased by approximately $25 \%$. However, Poland's 
economy remained heavily dependent on bituminous coal and lignite, so reforms of the energy sector were necessary in order to reduce Poland's emissions in the future. In addition to environmental considerations and the need to promote the economic efficiency and competitiveness of Polish industry, Poland faced international incentives to initiate such reforms. In April 1994 Poland formally applied to join the European Union, whose environmental programs focused on climate change policies as a top priority, so the common understanding was that Poland would "adopt policies and measures relating to climate change that are in accordance with those decided upon by the European Union." 19

Poland began experiencing pressure from the EU as soon as it opened accession negotiations. In fact, participants have noted that "environmental issues have been at the forefront of the negotiations between the EU and the applicant countries." ${ }^{20}$ Poland and other candidates for accession were required to adopt and implement all of the EU's environmental laws, which were included in the acquis communitaire. The only issue that was open for negotiations in the environmental sector was when each law would enter into force. Countries that could not fully meet EU requirements by the accession date could request transition periods, but the EU did not approve many of these requests. Poland was able to get more lenient terms than its neighbors: it applied for transition periods in nine sectors (including one air quality and three industrial pollution sectors), and was approved for seven, of which four transition periods were of the requested length. Poland was a special case because of the sheer magnitude of the environmental investments that were necessary to meet EU standards. For example, the cost to Poland

\footnotetext{
${ }^{19}$ UNFCCC 1998.

${ }^{20}$ Danish Environmental Protection Agency 2001.
} 
of satisfying the Large Combustion Plants requirements was estimated at 3.5 billion euros, which was double the size of the second largest investment required of any country in this category, the Czech Republic.

In addition to internal EU laws, the applicant countries were required to ratify all international environmental agreements to which the EU was a party. In some cases this requirement did not pose any additional obstacles for candidate states, as the EU's corresponding environmental legislation incorporated these obligations. However, as an operations officer of the Warsaw Office of the World Bank pointed out, "Poland signed many treaties without much investigation into their costs." ${ }^{21}$ As a consequence, Poland now has numerous obligations under these treaties that do not reflect its domestic priorities. The Kyoto Protocol was different in that respect as it was being negotiated at the same time as Poland and other EU applicants were negotiating with the EU. Postcommunist countries were able to insist on the inclusion of a special clause that would allow transition economies to use a year other than 1990 as the baseline for calculating emissions targets, and this was important for Poland because 1990 was a year of drastic economic contraction under the Balcerowicz Plan for rapid macroeconomic adjustment. As a result, Poland's 6\% emissions reduction target from its base year translated into a $15.5 \%$ increase in greenhouse gas emissions from the 1990 level. Moreover, Poland benefited from carbon sinks specified in the Marrakesh Accords: under the revised provisions, Poland could produce $17.4 \%$ more emissions than it did in 1990. Although the substantive effects presented in Table 3 underestimate Poland's level of $\mathrm{CO}_{2}$ emissions adjusted for Kyoto and Marrakesh quotas, these results are still informative: The Kyoto Protocol secured a positive effective quota for Poland, and Marrakesh

\footnotetext{
${ }^{21}$ Interview with Barbara Letachowicz, April 19, 2005.
} 
revisions increased the size of Poland's emissions allowance. However, Polish authorities were concerned that Poland would not be able to use its advantageous position, i.e. to sell its emissions rights, once it joined the EU. The EU member states formed an emissions 'bubble,' which redistributed emissions quotas assigned to each state. If the EU were to form a new bubble after expansion, the quota surplus that Poland hoped to sell could disappear. However, there was a clear understanding that Poland's ratification of the treaty was essential to the country's European future. Stanislaw Zelichowski, Polish Environment Minister, noted that joining the climate change agreement could "bring about essential political benefits to Poland in the context of European integration. ${ }^{, 22}$ Poland ratified the Kyoto Protocol in December 2002.

Once the Protocol was ratified, EU member states and applicants began to develop National Allocation Plans (NAPs), or statements specifying how each country would allocate its emissions rights. Poland, with its significant emissions surplus, might have been expected to receive the European Commission's endorsement of its NAP quite easily. In fact, however, that was not the case: the Commission would not approve the Polish plan until the country cut its planned emissions allowances by $16.5 \%$, or 141.3 million tons of $\mathrm{CO}_{2}$, for the period between 2005 and $2007 .{ }^{23}$ The Polish government attempted to revise the plan, but ran into significant opposition from Polish companies. Since Poland could not negotiate over the ruling of the European Commission, it sought to cut its allocations without hurting domestic industries. Jacek Piechota, the Polish minister of economic affairs, admitted that, "In the beginning we were quite anxious when the EC allocated a lower level of $\mathrm{CO}_{2}$ allocations, but we looked at our new

22 „Zelichowski: Poland May be Important for Kyoto Protocol.“ Polish Press Agency (PAP) News Wire. (July 25, 2002). LexisNexis.

23 “Poland Pushes EUAs to Year High.” Platts Power In Europe. (March 14, 2005). LexisNexis. 
balance and concluded we will survive." ${ }^{24}$ He explained that the Polish government intended to solve this problem by increasing its use of nuclear energy.

The contrast between the Russian and Polish cases could not be starker. Poland is a vibrant democracy with a fractious parliament and vigorous internal policy debates, and Russia is an ambiguous case, a country that holds elections but has many authoritarian features. In neither country, however, were domestic ratification constraints a factor. Where Russia played a high-stakes game of brinkmanship, secured emissions concessions and went on to demand additional concessions outside the Kyoto regime in return for its rather symbolic ratification, Poland accepted the deal that was handed down to it by the European Commission. It secured generous terms at Kyoto and Marrakesh, but was compelled to surrender its emissions quotas to the EU in return for accession. Polish ministers were so impressed by the need to speed the accession process that they signed every piece of paper the EU put in front of them, and the Polish Sejm ratified every piece of necessary enabling legislation. In one important sense, however, there is a striking parallel between Russia and Poland: both countries signed and ratified the Kyoto Protocol because the European Union offered compelling incentives.

\section{Conclusions}

In this paper, we present and test two competing models of the Kyoto process. The Kyoto Protocol provides an ideal opportunity to perform statistical analysis to test the theory of two-level games. The country-specific quotas negotiated under Kyoto provide a quantitative measure of bargaining outcomes, and enough time has passed for ratification data to be available for all of the signatories. Further, there is a prima facie

\footnotetext{
24 “Emission Trading Forces Fuel Mix Re-think." Platts Power in Europe. (March 2005). www.platts.com/Electric\%20Power/Resources/News\%20Features/polishpower/index_1.xml.
} 
case for such an interpretation. In the two most prominent cases, those of the United States and Russia, the politics of ratification appeared to be intimately connected to international bargaining.

This makes it all the more striking that we find no pattern in the Kyoto process consistent with a two-level bargaining hypothesis. Bargaining and ratification simply do not affect each other in the aggregate data, and prominent outliers do not have undue influence on the analysis. While we find ample evidence that domestic political constraints influence ratification, we find no evidence that these constraints or expectations about obstacles to ratification influenced the bargaining stage. Further, although we note that bargaining outcomes varied widely for a number of reasons, these country-specific outcomes did not influence the subsequent ratification decisions. Instead, in most of the countries that adopted binding emissions targets under the Kyoto Protocol and subsequently ratified the treaty, something much more powerful was at work that overwhelmed the effects of domestic constraints.

We find that the second approach offers a more plausible explanation of the Kyoto politics: The key factor in bargaining and ratification was the role played by the European Union. Members of the EU pushed for a more ambitious treaty than other countries were willing to adopt, bargained as a coalition, and ratified the accord in lock step after the Marrakesh agreement. Countries that applied to join the EU were required to adopt the Kyoto Protocol along with a host of other pieces of domestic legislation and international law, and although allowances were made for post-communist countries in transition, EU accession states swallowed more binding obligations than other states in the region. The case of Poland is particularly instructive in this respect: although 
formally receiving substantial excess quotas to sell at Kyoto and Marrakesh, Poland was subsequently compelled to surrender them by the European Commission as part of the accession process. Meanwhile, the Polish Sejm worked overtime to ratify every piece of legislation Brussels demanded. Domestic constraints were not binding. The case of Russia is similarly illuminating. Although this is a rare case in which ratification clearly was used as a strategic bargaining chip, it becomes clear on closer inspection that Russia's domestic politics did not constrain the Kyoto process. The Russian case illustrates the central role the EU played in creating incentives to ratify the Kyoto Protocol, because it was the EU's concessions-dropping objections to Russia's drive to join the WTO- that cleared the way for Russia to ratify.

There are broader lessons to be drawn from the Kyoto experience. First, while domestic politics can play a key role in international bargaining, countries may be able to expand their influence when they pool their sovereignty, and this tends to dampen the effects of domestic political factors. Second, domestic factors can also be overridden by the asymmetries of international power. Domestic politics played such a decisive role in the case of the United States because the U.S. is one of the few countries powerful enough to be beyond the reach of European diplomacy. Third, these results should be read as a cautionary tale for those who would treat the U.S. isolation over the Kyoto Protocol as a sign of a growing international consensus in favor of environmental regulation. Rather, we find that almost all of the countries that adopted restrictions on their carbon emissions at Kyoto were either members of the European Union or countries that hoped to become members in the near future, and that it was the immediacy of ongoing accession talks that gave the EU leverage in Eastern Europe. Kyoto was 
essentially a European project, and what modest success it achieved relied almost exclusively on European diplomatic efforts. Indeed, we present evidence that countries with secure membership were less pliable than applicants. Consequently, we can expect that the new members will be reluctant to make further environmental concessions, now that their membership is secure. 
Table 1: Ratification Model

$$
\begin{aligned}
& \text { Ex ante After Kyoto } \begin{array}{c}
\text { After } \\
\text { Marrakesh }
\end{array} \text { After Kyoto } \begin{array}{c}
\text { After } \\
\text { Marrakesh }
\end{array} \\
& \text { (Full sample) ～(Annex B sample) }
\end{aligned}
$$

Effective quotas after Kyoto

Effective quotas after Marrakesh

$(-0.64)$

1.00 1.00

EU15

EU applicant (first group)

EU applicant (second group)

GDP

Population

Legislative election timing

Left-right

Parliamentary

Opposition majority (house)

Fractionalization

Annex B country

OPEC

/In_p

\begin{tabular}{|c|c|c|c|c|c|c|c|c|c|}
\hline & & & & $(-0.76)$ & 1.00 & & & . & 1.00 \\
\hline & 3.78 & & 2.84 & & 2.79 & & 36.26 & & 35.80 \\
\hline 33) & & (2.89) & & (2.83) & & (2.93) & & (2.90) & \\
\hline & 3.71 & & 2.91 & & 2.86 & & 22.15 & & 21.83 \\
\hline 80) & & (2.43) & & 2.38) & & 2 & 21.56 & ..64) & \\
\hline .58) & & (2.98) & & (2.93) & & $(2.98)$ & & (2.97) & \\
\hline .31) & 1.00 & $(-0.82)$ & 1.00 & $(-0.93)$ & 1.00 & $(0.15)$ & 1.00 & $(0.11)$ & 1. \\
\hline ..29) & 1.00 & (1.17) & 1.00 & $(1.21)$ & 1.00 & $(-0.22)$ & 1.00 & $(-0.17)$ & 1. \\
\hline 0.37$)$ & 1.00 & $(-1.94)$ & 0.99 & $(-1.94)$ & 0.99 & $(-0.48)$ & 0.99 & $(-0.48)$ & 0. \\
\hline & 1.07 & & 1.08 & & 1.08 & & 0.27 & & 0.27 \\
\hline 1.20) & 1.32 & (1.44) & 1.39 & (1.43) & 1.39 & $\begin{array}{l}(-2.08) \\
(3.68)\end{array}$ & 8.33 & $\begin{array}{l}(-2.09) \\
(3.79)\end{array}$ & 8. \\
\hline-0.67$)$ & 0.43 & (0.86) & 2.40 & (0.86) & 2.40 & $(-3.41)$ & & $(-4.25)$ & 0. \\
\hline 1.23) & 2.03 & $(-0.05)$ & 0.98 & $(-0.05)$ & 0.98 & $(0.45)$ & 2.45 & $(0.47)$ & 2. \\
\hline & 0.43 & & 0.65 & & 0.66 & & & & \\
\hline $\begin{array}{r}3.92 \\
-27.34\end{array}$ & $\begin{array}{l}E-07 \\
)\end{array}$ & $\begin{array}{r}\mathbf{8 . 7 8} \\
(-33.35)\end{array}$ & 8E-08 & $\begin{array}{r}\mathbf{8 . 7 7} \\
(-33.37)\end{array}$ & 7E-08 & & & & \\
\hline & 1.0 & & 1. & & 1.03 & & 2.6 & & 2.69 \\
\hline $\begin{array}{l}\text { (9.05) } \\
\text { 12) } 89\end{array}$ & 8.73 & $\begin{array}{l}(8.90) \\
(13) 15\end{array}$ & & $\begin{array}{l}(8.90) \\
(13) 15\end{array}$ & 44.70 & $\begin{array}{l}(11.27) \\
(11) 25\end{array}$ & 59.22 & $\begin{array}{l}(11.27) \\
(11) 320 .\end{array}$ & 190 \\
\hline
\end{tabular}

Wald chi2

Number of observations

7,603

7,761

7,761

1,906

1,906

Note: Weibull estimates; reported information - hazard ratios and z-statistics. 95\% confidence level when in bold. Time span: 1997-2003.. 
Figure 1: Survival Functions for Annex B Sample Weibull Model from Table 1 (with Effective Quotas after Kyoto)
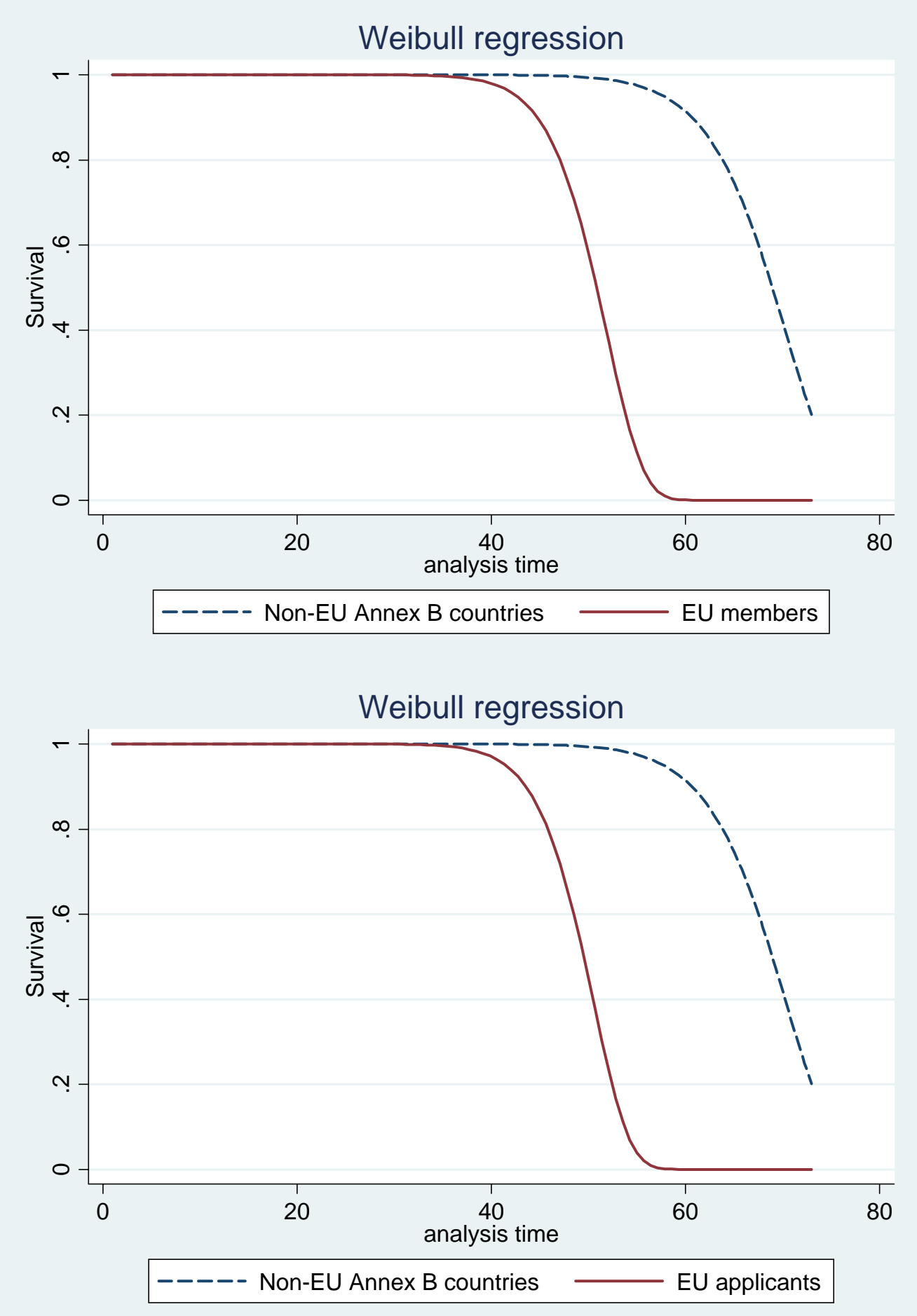
Table 2: Effective $\mathrm{CO}_{2}$ Quotas Model

\begin{tabular}{|c|c|c|c|c|c|c|}
\hline \multirow{4}{*}{ Predicted ratification } & \multicolumn{2}{|c|}{$\begin{array}{l}\text { Effective Quotas after Kyoto } \\
\text { (1997; full sample) }\end{array}$} & $\begin{array}{c}\text { Effective } \\
\text { Quotas after } \\
\text { Kyoto } \\
(1997)\end{array}$ & $\begin{array}{c}\text { Effective } \\
\text { Quotas after } \\
\text { Kyoto } \\
(1997)\end{array}$ & $\begin{array}{l}\text { Effective } \\
\text { Quotas } \\
\text { after } \\
\text { Marrakesh } \\
(2001)\end{array}$ & $\begin{array}{l}\text { Effective } \\
\text { Quotas } \\
\text { after } \\
\text { Marrakesh } \\
\text { (2001) }\end{array}$ \\
\hline & \multicolumn{3}{|c|}{ (bootstrapped) } & \multicolumn{2}{|c|}{ (Annex B sample) } & \\
\hline & 0.21 & -0.58 & & & & \\
\hline & $(0.17)$ & $(-0.26)$ & & & & \\
\hline EU15 & $-33,017$ & $-33,484$ & 16,666 & 111 & 16,480 & -174 \\
\hline & $(-0.86)$ & $(-0.88)$ & $(0.84)$ & $(0.02)$ & $(0.77)$ & $(-0.02)$ \\
\hline $\begin{array}{l}\text { EU applicant (first } \\
\text { group) }\end{array}$ & $-42,569$ & $-41,125$ & $-294,881$ & $-248,100$ & $-301,424$ & $-251,816$ \\
\hline & $(-0.94)$ & $(-0.93)$ & $(-3.60)$ & $(-6.79)$ & $(-3.58)$ & $(-7.47)$ \\
\hline group & $-50,533$ & $-47,885$ & $-301,229$ & $-256,020$ & $-306,027$ & $-258,260$ \\
\hline GDP & ${ }^{(-1.15)}-0.10$ & $\begin{array}{ll}(-1.09) & -0.10 \\
(-1.41) & \end{array}$ & ${ }^{(-3.82)}-0.03$ & $\begin{array}{ll}(-10.22) & -0.02 \\
(-0.95)^{-} & \end{array}$ & ${ }^{(-3.12)}-0.02$ & $\begin{array}{l}(-10.89)^{0.00} \\
(-0.26)^{0.00}\end{array}$ \\
\hline Population & $(1.31)^{141}$ & $(0.92)$ & $(5.04)^{2,715}$ & $\begin{array}{ll} & 1,949 \\
(4.22) & \end{array}$ & $(5.30)^{\mathbf{2 , 7 5 0}}$ & $(4.66)^{1,940}$ \\
\hline $\mathrm{CO}_{2}$ emissions & $(-0.87)^{-0.11}$ & $\begin{array}{ll}(-0.59) & -0.08\end{array}$ & $(-13.55)^{-0.33}$ & $(-26.96)^{-0.31}$ & $\begin{array}{r}-0.32 \\
(-11.37)^{-0}\end{array}$ & $\begin{array}{r}-0.30 \\
(-21.39)^{-0}\end{array}$ \\
\hline Post-communist & $\begin{array}{l}\text { 46,999 } \\
(2.11)\end{array}$ & $(2.04)^{45,261}$ & $\begin{array}{l}351,903 \\
(4.35)\end{array}$ & $\begin{array}{l}2^{286,681} \\
(11.78)\end{array}$ & $\begin{array}{l}\text { 358,392 } \\
(4.26)\end{array}$ & $\begin{array}{l}290,355 \\
(13.33)\end{array}$ \\
\hline Land area & $(1.91)^{0.02}$ & $(1.82)$ & $\begin{array}{ll} & 0.02 \\
(2.84) & \end{array}$ & $\begin{array}{ll} & 0.01 \\
(5.00) & \end{array}$ & $(3.43)^{0.02}$ & $(7.65)^{0.01}$ \\
\hline Forest & $\begin{array}{l}22,179 \\
(1.35)\end{array}$ & $(1.31)^{21,456}$ & $(0.39)^{12,346}$ & $(-1.01)^{-26,237}$ & ${ }^{10.59)}$ & $\begin{array}{l}-23,676 \\
(-0.94)\end{array}$ \\
\hline Annex B country & $\begin{array}{l}55,014 \\
(1.45)\end{array}$ & $(1.36)^{52,158}$ & & & & \\
\hline Russia & & & & $\begin{array}{l}367,513 \\
(10.33)\end{array}$ & & $\begin{array}{l}393,918 \\
(11.45)\end{array}$ \\
\hline Constant & $\begin{array}{l}-15,626 \\
(1.45)\end{array}$ & $(1.64)^{-14,639}$ & $\begin{array}{l}-37,744 \\
(-1.63)\end{array}$ & $(0.35)^{2,069}$ & $\begin{array}{l}-42,865 \\
(-1.69)\end{array}$ & $(-0.00)^{-28}$ \\
\hline $\mathrm{R}^{2}$ & 0.83 & & 0.98 & 0.99 & 0.98 & 0.99 \\
\hline Jumber c & 133 & 133 & 35 & 35 & 35 & 35 \\
\hline
\end{tabular}


Table 3: Bargaining Outcomes: Marginal Effects and Predicted Values for Annex B countries

\author{
Effective Quota Effective Quota \\ after Kyoto after Marrakesh
}

Marginal effects:

EU member

$\begin{array}{rr}16,666 & 16,480 \\ -294,881 & -301,424 \\ -301,229 & -306,027\end{array}$

Predicted values:

\section{Mean}

Average EU member

Average EU applicant

U.S.A.

Russia

Poland
$-22,871$

$-23,665$

$-35,216$

$-1,270,992$

519,596

19,612
$-9,748$

$-20,340$

$-38,640$

$-1,114,640$

615,000

33,241

Kilotons of $\mathrm{CO}_{2}$ 


\section{References}

Abdelal, Rawi. 2007. Capital Rules: The Construction of Global Finance. Cambridge: Harvard University Press.

Alesina, Alberto, and Allen Drazen. 1991. Why Are Stabilizations Delayed? American Economic Review 81: 1170-88.

Barton, John H., Judith L. Goldstein, Timothy E. Josling, and Richard H. Steinberg. 2006. The Evolution of the Trade Regime: Politics, Law, and Economics of the GATT and the WTO. Princeton: Princeton University Press.

Bayne, Nicholas, and Robert Putnam. 1984. Hanging Together: Cooperation and Conflict in the Seven-Power Summits. Cambridge: Harvard Univ. Press. Revised Edition, 1988.

Beck, Katz and Tucker. 1998. Taking Time Seriously: Time-Series-Cross-Section Analysis with a Binary Dependent Variable. American Journal of Political Science 42(4): 1260-88.

Byrd-Hagel. 1997. Resolution Expressing the Sense of the Senate Regarding the Conditions for the Untied States Becoming a Signatory to any International Agreement on Greenhouse Gas Emissions under the United Nations Framework Convention on Climate Change. $105^{\text {th }}$ Congress, $1^{\text {st }}$ Session, S. Res. 98 (July 25).

Bodansky, Daniel. 2001. The History of the Global Climate Change Regime. In Urs Luterbacher and Detlef F. Sprinz, eds., International Relations and Global Climate Change. Cambridge, Mass.: MIT Press.

Evans, Peter B., Harold Jacobson and Robert Putnam, eds. 1993. Double-Edged Diplomacy: International Bargaining and Domestic Politics. Berkeley: University of California Press.

Fairman, David. 1996. The Global Environment Facility: Haunted by the Shadow of the Future. In Keohane, Robert O., and Marc A. Levy, Institutions for Environmental Aid: Pitfalls and Promise. Cambridge, Mass.: MIT Press.

Fearon, James D. 1994. Signaling versus the Balance of Power and Interests: An Empirical Test of a Crisis Bargaining Model. Journal of Conflict Resolution 38 (June 1994, Special Issue): 236-69.

Fearon, James D. 1998. Bargaining, Enforcement, and International Cooperation. International Organization 52 (Spring): 269-306. 
Gartzke, Erik, Dong-Joon Jo, and Richard Tucker. 1999. The Similarity of UN Policy Positions, 1946-96. Version 2.5.

http://www.vanderbilt.edu/ rrtucker/data/a_nity/un/similar

Danish Environmental Protection Agency. 2001. The Environmental Challenge of EU Enlargement in Central and Eastern Europe. Retrieved August 3, 2005, from http://www.mst.dk/udgiv/Publications/2001/87-7972-044-7/html/default_eng.htm

Den Elzen, M.G. J. and A. P. G. de Moor. 2001. The Bonn Agreement and Marrakesh Accords: An Updated Analysis. RIVM Report 728001017. National Institute of Public Health and the Environment, Bilthoven, The Netherlands.

Downs, George W., David M. Rocke, and Peter N. Barsoom. 1998. Managing the Evolution of Multilateralism. International Organization 52 (Spring): 397-419.

Grieco, Joseph. 1990. Cooperation Among Nations: Europe, America, and Non-tariff Barriers to Trade. Ithaca: Cornell University Press.

Hanson, Brian T. 1998. What Happened to Fortress Europe? External Trade Policy Liberalization in the European Union. _International Organization 52 (1) (Winter): 5586.

Helleiner, Eric. 1994. States and the Reemergence of Global Finance: From Bretton Woods to the 1990s. Ithaca: Cornell Univ. Press.

Henning, C. Randall. 1998. Systemic Conflict and Monetary Integration in Europe. International Organization 52 (3) (Summer): 537-74.

Keohane, Robert O., Stephen Macedo and Andrew Moravcsik. 2009. DemocracyEnhancing Multilateralism. International Organization 63 (1) (Winter): 1-31.

Krasner, Stephen D. 1985. Structural Conflict : The Third World against Global Liberalism. Berkeley : University of California Press.

Leventoğlu, Bahar, and Ahmer Tarar. 2005. Prenegotiation Public Commitment in Domestic and International Bargaining. American Political Science Review 99 (3):419433.

London, Tamar R. 2002. Leaders, legislatures, and international negotiations : a twolevel game with different domestic conditions. Ph.D. dissertation, University of Rochester.

Mansfield, Edward D., Helen V. Milner, and B. Peter Rosendorff. 2000. Free to Trade: Democracies, Autocracies and International Trade. American Political Science Review 94 (2) (June): 305-22. 
Martin, Lisa L. 2000. Democratic Commitments: Legislatures and International Cooperation. Princeton, N.J.: Princeton University Press.

Meunier, Sophie. 2005. Trading Voices: The European Union in International Commercial Negotiation. Princeton: Princeton University Press.

Milner, Helen, V. 1997. Interests, Institutions and Information: Domestic Politics and International Relations. Princeton: Princeton University Press.

Moravcsik, Andrew. 1998. The Choice for Europe: Social Purpose and State Power from Messina to Maastricht. Ithaca: Cornell Univ. Press.

Pollack, Mark A. 2003. The Engines of European Integration: Delegation, Agency and Agenda Setting in the European Union. New York: Oxford University Press.

Putnam, Robert D. 1988. Diplomacy and Domestic Politics. International Organization 42 (3) (Summer): 427-61.

Rubinstein, Ariel. 1982. Perfect equilibrium in a bargaining model. Econometrica 50: 97-109.

Schneider, Gerald and Lars-Erik Cederman. 1994. The Change of Tide in Political Cooperation: A Limited Information Model of European Integration. International Organization 48, No. 4 (Autumn): 633-62.

Schultz, Kenneth. 2001. Democracy and Coercive Diplomacy. Cambridge: Cambridge University Press.

Sprinz, Detlef F. and Martin Weiß. 2001. Domestic Politics and the Global Climate Policy. In Urs Lutterbacher and Detlef F. Sprinz, eds., International Relations and Global Climate Change. Cambridge, Mass.: MIT Press.

Tarar, Ahmer. 2001. "International Bargaining with Two-Sided Domestic Constraints." Journal of Conflict Resolution 45(3):320-340.

Thomson, Robert, Frans N. Stokman, Christopher H. Achen and Thomas Konig, eds. 2006. The European Union Decides. Cambridge: Cambridge University Press.

UNFCCC. 1997. Kyoto Protocol. Retrieved August 3, 2005, from

http://unfccc.int/essential_background/kyoto_protocol/items/1678.php

UNFCCC. 1998. Summary of the Report of the In-depth Review of the National Communication of Poland. United Nations Framework Convention on Climate Change. Retrieved August 3, 2005, from http://unfccc.int/resource/docs/sum/pol01.htm

Walters, Greg. 2004. Kyoto, WTO Deals Hang in Balance. CDI Russia Weekly (21 May 2004). Retrieved August 8, 2005, from http://www.cdi.org/russia/307-14.cfm 
Ward, Hugh, Frank Grundig and Ethan Zorick. 2001. "Marching at the Pace of the Slowest: A Model of International Climate-Change Negotiations." Political Studies 49: 438-461.

Wiegandt, Ellen. 2001. Climate Change, Equity, and International Negotiations. In Urs Lutterbacher and Detlef F. Sprinz, eds., International Relations and Global Climate Change. Cambridge, Mass.: MIT Press. 


\section{Appendix A: Construction of the Effective $\mathrm{CO}_{2}$ Quota Variable}

The effective $\mathrm{CO}_{2}$ quota is a variable that measures the difference between emissions quotas and projected emissions for each Annex B country, and is intended to measure the anticipated degree of economic adjustment required to meet the quota. Negative values indicate that projected emissions exceed the quota, requiring adjustment, while positive values represent projected excess quotas, which can be sold to other regime participants. These are calculated both for the Kyoto Protocol and the Marrakesh Accords. For non-Annex B countries, this variable takes the value zero, because these countries are under no obligation to restrict their $\mathrm{CO}_{2}$ emissions; effectively, we assume that their emissions quotas are equal to their emissions levels. No adjustment is necessary, and no excess quotas are possible.

The raw data on quotas were expressed in terms of percentages of 1990 emissions

levels. For Annex B countries, therefore, we multiplied emissions quotas from the Kyoto Protocol and the Marrakesh Accords by $\mathrm{CO}_{2}$ production in 1990 to obtain emissions quotas in kilotons. For instance, in 1990 Canada produced $428842 \mathrm{kt}$ of $\mathrm{CO}_{2}$ emissions, and its Kyoto quota was 94\%, so Canada's emissions quota in the commitment period 2008 to 2012 had to be limited to $403,111 \mathrm{kt}$.

To project what countries' emissions would be in the absence of Kyoto and Marrakesh limitations, we regressed $\mathrm{CO}_{2}$ emissions data for the period 1990 to 2000 using the following fixed-effects equation:

$Y_{i t}=\alpha_{i}+\beta X_{i t}+\varepsilon_{i t}$ 
where $i$ indexes countries, $t$ indexes years, $Y$ is a variable measuring $\mathrm{CO}_{2}$ emissions, $\alpha$ represents time-invariant country-level effects, $X$ is a vector of regressors (post_communist, GDP_growth, GDP, population, and land_area), and $\varepsilon$ is a stochastic error term.

Table A1 presents the coefficients and standard errors [Table A1 about here].

\section{Table A1: Forecasting $\mathrm{CO}_{2}$ emissions}

\begin{tabular}{lc} 
& Dependent variable: $\mathrm{CO}_{2}$ emissions \\
\hline Post-communist & $-81,747$ \\
GDP growth & $(50,932)$ \\
& -294.5 \\
GDP & $(144.40)$ \\
& 0.147 \\
Population & $(0.04)$ \\
& 3,122 \\
Land area & $(573.00)$ \\
& -12.9 \\
Constant & $(33.00)$ \\
& $9.8 \times 10^{6}$ \\
$\mathrm{R}^{2}$ & $\left(2.5 \times 10^{7}\right)$ \\
Observations & 0.39 \\
\hline OLS; Robust standard errors in parentheses & 1,892
\end{tabular}

The predicted values of $\mathrm{CO}_{2}$ emissions were subtracted from emissions quotas to create the effective $\mathrm{CO}_{2}$ quota variable.

Figures A1 and A2 (below) plot emissions projections against actual $\mathrm{CO}_{2}$ emissions to demonstrate the fit of the equation (the variables are correlated at .95). [Figures A1 and A2 about here.] 
Figure A1: Actual $\mathrm{CO}_{2}$ emissions vs. projected emissions for all countries of the world, for the period of $1990-2000$, with $95 \%$ confidence interval

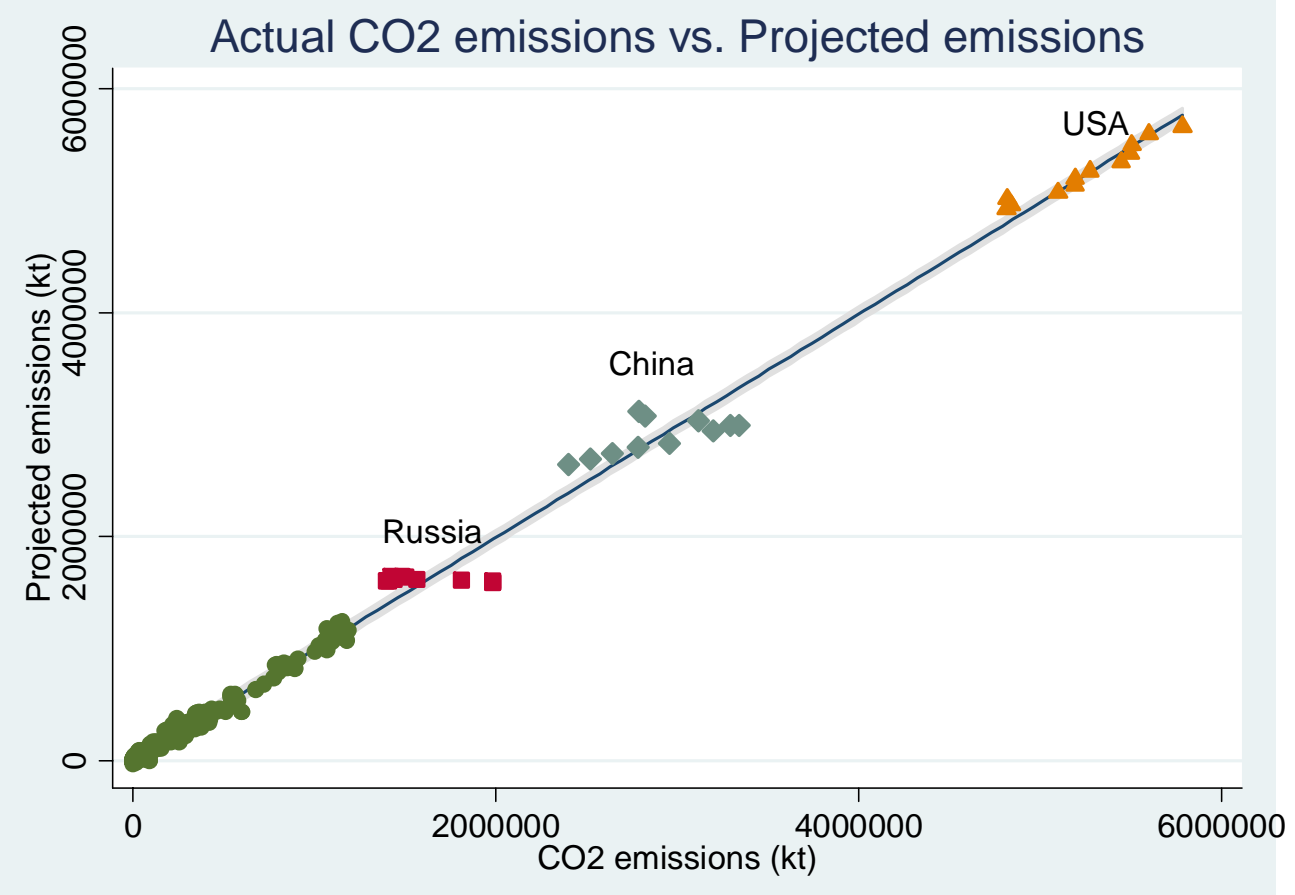

Figure A2: Actual $\mathrm{CO}_{2}$ emissions vs. projected emissions for all countries of the world, December 1997, with $95 \%$ confidence interval

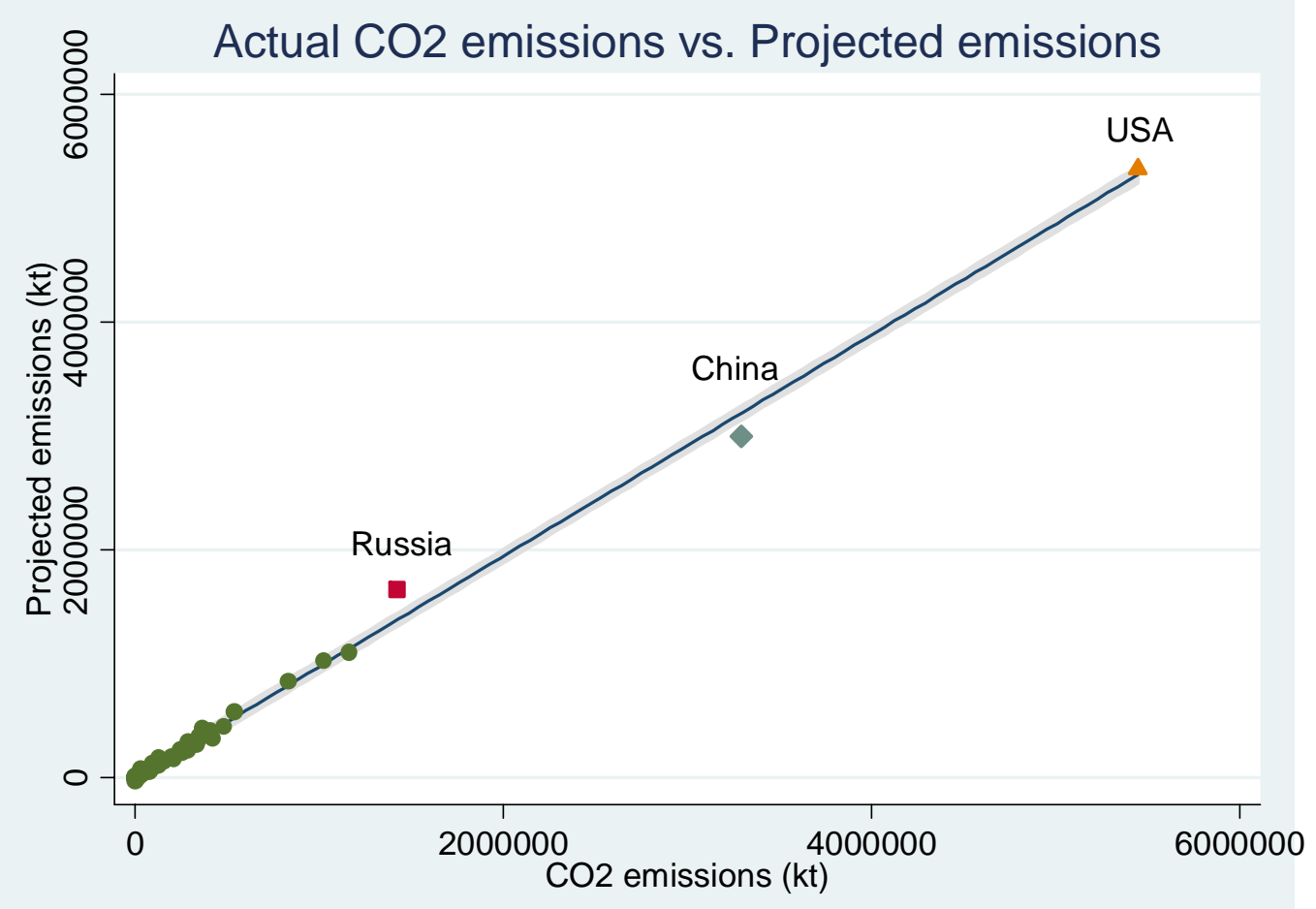




\section{Appendix B: Robustness Checks with Alternative Measures}

To conduct robustness checks, we constructed two alternative measures of effective emissions quotas. Each of these variables represents the difference between the country's emissions quota and its $\mathrm{CO}_{2}$ output. The output measured in 1997 was used for the effective Kyoto quotas variable, while for effective Marrakesh quotas we used the output measured in 2001 (i.e. we chose the years when these two agreements were adopted). The new variables take positive values for emissions surplus and negative values for emissions reductions, similarly to our original measures. When we replaced the original variables with their respective alternative measures, our findings remain unaffected. The influence of the EU remains robust and in the expected direction. Due to space limit, we only report results based on Table 1 - see Table B1. A full set of tables with robustness checks is available upon request. [Table B1 about here]

Note that since the new variables do not rely on projected emissions, they represent short-term costs and benefits of the climate change agreements. Governments, on the other hand, took into account long-term effects of implementing the agreements as well as their countries' economic prospects in addition to their circumstances in a given year. Therefore, our original variables are more appropriate measures of such long-term considerations. The example of Australia, an Annex B country that did not ratify the Protocol, can illustrate the limitation of the new variables. Unlike the original measure, the new Kyoto quotas variable indicates that Australia would have emissions surplus because under the Protocol Australia would have the right to emit more than it did in 1990. However, Australia's emissions continued growing after 1997, and in the long run this country would have to cut $\mathrm{CO}_{2}$ output if it ratified the Protocol. Thus, the reliance on 
emissions data from one year makes the new measures vulnerable to short-term $\mathrm{CO}_{2}$

fluctuations that may not be representative of long-term prospects.

\section{Table B1: Ratification ex ante and ex post (Full Sample)}

After Kyoto

(Full sample)

Effective quotas after Kyoto
Effective quotas after Marrake
EU15
EU applicant (first group)
EU applicant (second group)
GDP
Population
Legislative election timing
Left-right
Parliamentary
Opposition majority (house)
Fractionalization
Annex B country
OPEC

Wald chi2
1.00

akesh

$$
(-1.49)
$$

\subsection{4}

(2.85)

\subsection{3}

(2.31)

\subsection{3}

(3.06)

1.00

$(-1.43)$

1.00

(1.48)

0.99

$$
(-1.93)
$$

1.08

(0.63)

1.35

(1.31)

2.39

(0.86)

0.98

$(-0.03)$

0.74

$(-0.82)$

\subsection{E-08}

$(-33.43)$

1.03

(8.89)

(13)

1544.35

After
Marrakesh
mple)

After Kyoto

After

Marrakesh

(Annex B sample)

1.00

$(-0.98)$

\subsection{0}

$(-1.02)$

\subsection{7}

(2.76)

2.78

(2.34)

2.39

(2.96)

1.00

$(-1.10)$

1.00

(1.29)

0.99

$(-1.93)$

1.08

(0.63)

1.37

(1.37)

2.39

(0.86)

0.98

$(-0.03)$

0.69

$(-0.92)$

8.73E-08

$(-33.40)$

1.03

(8.90)

(13)

1544.97
1.00

$(-0.18)$

$26.59 \quad 33.91$

(2.75) (2.83)

$15.63 \quad 20.52$

(2.43) (2.53)

$16.52 \quad 20.25$

(2.89) (2.91)

$1.00 \quad 1.00$

$(-0.80) \quad(-0.05)$

$1.01 \quad 1.00$

(0.58) (-0.04)

$0.99 \quad 0.99$

$(-0.45) \quad(-0.45)$

$\mathbf{0 . 2 6} \quad \mathbf{0 . 2 7}$

$(-2.19) \quad(-2.11)$

6.31 $\quad 7.75$

(3.59) (3.31)

$\mathbf{0 . 0 0} \quad \mathbf{0 . 0 0}$

$(-3.37) \quad(-3.02)$

$7.78 \quad 3.36$

(0.93) (0.57)
2.70

2.69

(11.75)

(11.29)

Number of observations

7,761

7,761

Note: Weibull estimates; reported information - hazard ratios and z-statistics.

95\% confidence level when in bold. Time span: 1997-2003. 